УДК 355.4(44):504

DOI 10.17072/2219-3111-2021-2-17-26

Ссылка для цитирования: Le Gall E. The French $47^{\text {th }}$ Infantry Regiment during the First World War: An Environmental Approach // Вестник Пермского университета. История. 2021. № 2(53). C. $17-26$.

Link for citation: Le Gall E. The French $47^{\text {th }}$ Infantry Regiment during the First World War: An Environmental Approach // Perm University Herald. History (Vestnik Permskogo universiteta. Istoriya). 2021. № 2(53). P. 17-26.

\title{
THE FRENCH 47TH INFANTRY REGIMENT DURING THE FIRST WORLD WAR: AN ENVIRONMENTAL APPROACH
}

\section{E. Le Gall}

Center for Research on Breton and Celtic (CRBC EA 4451 / UMS 3554), University Rennes II legallerwan@ymail.com ORCID: 0000-0001-7807-4569

ResearcherID: E-1884-2014

The First World War can be examined from the perspective of traditional military history as well as the perspective of the relationship between combatants and the environment. The author reveals based on a wide range of archival materials, printed media and ego-documents (diaries, memoirs, letters) the question of combat peculiarities of the 47th Infantry Regiment of the French Army considering with the influence of environmental conditions on the soldiers. The author demonstrates the dependence of the regiment's intensity and efficiency of combat operations on the terrain, weather and climate changes on the Western Front of the First World War. In the first phase of the conflict, soldiers were extremely vulnerable to even the slightest temperature changes (extreme heat, cold) due to their uniforms' problems. Physical strain from long marches across unfamiliar terrain and an extended stay in the trenches also harmed their health. The combat unit's active influence on the environment is also emphasised, with the pollution of the battlefield by sewage, leftover ammunition and weapons. The soldiers' health being adversely affected by the polluted environment (above all, the spread of contagious diseases, poisoning by chemical and metal warfare agents) is also considered. Severe environmental changes during battles also made combat operations more difficult. Thus, during the First World War, both the soldiers of the 47th Infantry Regiment of the French Army and all the other poilus became hostages to a severely altered environment due to the impact of millions of combatants.

Keywords: French army, the First World War, infantry, 47th regiment, environmental approach.

As torn between the two opposing poles of the so-called «consent» and «constraint» schools, French historiography of the First World War paid little attention to the environment. It is not certain, moreover, that this lack of interest was solely French. In their masterly summation published in 2004, A. Prost and J. Winter said nothing about this, and it does not seem that the centenary of the conflict has helped to fill in what appears to be a blind spot [Prost, Winter, 2004]. We, in our thesis, defended in December 2019 and devoted to the $47^{\text {th }}$ infantry regiment (IR) of Saint-Malo during the Great War, have passed over this approach in silence, even though it is a source of profound renewal of knowledge [Le Gall, 2019]. It is this gap that we wish to fill here.

Environmental history, as a specific category of analysis, is challenging to define because its methodological frameworks have significantly evolved since its beginnings in the 1960s. Moreover, this field does not exactly overlap with the same questions in Europe, North America and Asia (for a historiographical review in French [Locher, Quenet, 2009], [Fressoz et al., 2014], War Studies are singularly absent from this panorama). Therefore, we will limit ourselves here to a loose definition and focus on what surrounds the infantrymen of the $47^{\text {th }}$ IR during the First World War. In other words, we will apprehend the regiment in its environment by focusing our attention on elements too often ne- 
glected by historiography such as the soil, the water tables or the weather conditions. Given that nature is a constructed reality, the analysis will draw from the repertoire of action of cultural history but also social history, history of technology, history of medicine and, of course, military history. Finally, we will place ourselves under the sign of ecology, a science that studies living beings in their environments, taking into account their interactions with the space in which they evolve.

A man at war is, in fact, part of a double relationship with the environment. Constrained by the space into which he is projected, the soldier also affects the theatre of operation on which he fights [Cabanes, 2018, p. 99]. It is this duality that we would like to examine on the scale of the $47^{\text {th }}$ IR by returning first to war as practiced by the unit at ground level and then by considering the regiment from the angle of pollution. In doing so, a crucial and little-known issue of the Great War will be revealed: the domestication of nature by the belligerents.

\section{Seize the war at ground level}

The ground report on a unit such as the $47^{\text {th }}$ IR during the First World War needs focusing on the terrain on which infantrymen move and getting as close as possible to the combat experience. Such a reporting is, moreover, one of the methodological ambitions of environmental history, emphasized in the early 1970s by R. Nash: to deliver a narrative that is «from the bottom up» [Nash, 1972].

From the point of view of the First World War, a conflict that pitted millions of men against each other for 52 months on a wide variety of battlefields, conjugating the word «front» in the singular is meaningless. The theatres of operations are very diverse, and the singular of this expression does not manage to restore the plurality of the experiences: combat in the flooded plains of Flanders has little to do with the situation which can prevail in the mountains, Caporetto in Italy, Dobro Polje in Macedonia or the Carpathians. Moreover, with this diversity of topographies comes to be added the diachronic perspective: to fight at night in winter, snow or mud, is not the same thing as to carry out the offensive in full daylight, in full summer, under oppressive heat. Not to mention that between 1914 and 1918, the material environment of the armies, and especially uniforms and armaments, evolved greatly.

The $47^{\text {th }}$ IR of Saint-Malo is a good illustration of this impossible reduction of the notion of the «Great War front» to a single topographical reality. At the beginning of October 1914, the regiment was engaged south of Arras, in the middle of openfields whose flatness was only thwarted by a few hamlets: Beaurains, Neuville-Vitasse and Mercatel [Le Gall, 2014b, p.117-130]. Without a doubt, this environment is not very different from the surroundings of Chilly, a small village of the Somme that the regiment is charged to take back in September 1916. Here again, the plain is only interrupted by a few hamlets and two small forests which are as many points on which the belligerents cling: Browning Wood and Frédéric Wood (SHD-DAT, 26 N 636/9, JMO 47th IR, 30 April 1917). However, in the spring of 1917, the regiment moved to a completely different theatre of operations, Mount Cornillet. This massif only reaches an altitude of 200 meters, and should not be confused with high mountains. In that case, it was presented by the press as dominating «the plain of Nauroy between the massif of Moronvilliers and the heights of Berry» («Comment fut pris le Mont Cornillet», L'Ouest-Éclair, 1917, June 3, № 6420, p.2). The result was a theatre of operations all the more different from the biotope in which the infantrymen of the $47^{\text {th }}$ IR could operate in October 1914, as the Germans erected several «forts» enhanced with machine-gun nests and constituting as many «impassable obstacles» (SHDDAT, 26 N 636/9, JMO 47th IR, 30 April 1917). In other words, it is a configuration that has nothing to do with the terrain on which the unit received its baptism of fire in August 1914: the Borinage is a heavily wooded coalfield, crossed by the loops of the Sambre, and dotted with houses with blackened brick walls [Lanrezac, 1920, p.150]. The density is such that one is entitled to wonder if it is not a kind of urban combat. In the same way, it is more to the battle of Algiers (1957) than to the representations classically associated with the Great War that the combats of the $47^{\text {th }}$ IR lead us to think, in the spring of 1915, north of Arras, in the dreaded sector of the Labyrinth [Le Gall, 2014b, p.135].

The regiment's environment is all the more variable as the belligerents themselves influenced the topographical reality of the battlefield. Ange Godard returned in June 1917 to Verdun sector, where he performed his military service in the early 1900s, and recognized nothing of the landscape (Arch. dép. Ille-et-Vilaine, $1 \mathrm{R}$ 1931.598). Indeed, the archives describe a land ploughed by shells (650 shells fall every day in this sector). Also, the soil was washed away by torrential rains that finish laminating the ground and destroying what remains of the trenches (for further developments we refer 
to [Le Gall, 2017, p. 221-222] in particular). The geographical coordinates may be the same, but the theatre of operation is completely different.

\section{Retrieve the combat experience}

In the 1970s, J. Keegan placed this attention to the material conditions of combat at the heart of the historiographical revolution with his Anatomy of Battle [Keegan, 2012]. The British master recommends returning to the field and observing the war at ground level criticizing the overly caricatural approach to warfare composed with «drum and trumpets» rhythm, heroic frescoes in which all individuals, like automatons, would evolve in the same way on the battlefield [Audoin-Rouzeau, Becker, 2000; Prost, 2002, p. 95-102]. In other words, it is a matter of getting out of the kriegsspiel above ground to focus on the reality of operations, which cannot be done without taking into account the environment in which they develop.

The stakes are high because clichés are so hard to come by, indicating at the same time a certain incapacity of history to have a lasting influence on public debate and mental representations. In France, the «myth of red pants» is still deeply rooted in memory. Thus, for example, J. Pellistrandi, a general officer and doctor of history, is not afraid to mention, in a recently published article, «the overly visible uniform» as one of the causes of the French army's failures in the summer of 1914 [Pellistrandi, 2020, p. 72].

However, apprehending the Great War of the $47^{\text {th }}$ IR through the environment not only allows us to put an end to the myth of the «red pants», but also to bring back into the light a certain number of aspects that constitute as many dead angles of the combatant experience. This is the case with soldiers' fatigue that was completely obscured by these regimental histories, which offer accounts of campaigns that de-realize the warfare because of the political imperative, in the early 1920s, paying homage to the victorious army and the poilu, the true hero of the conflict [Historique du $47 \mathrm{e}$ régiment d'infanterie, 1920]. A. Farge rightly reminds us, this occultation is a «real taboo of official history, since if it will be noble at the end of the conflict to have died in the field of honour, on what field of honour will it be noble to be exhausted to the point of death?» [Allard, 2010, p. 41].

\section{The weight of mud}

These words may be used for a situationof very first days of the Great War for the $47^{\text {th }}$ IR. From 15 August 1914, the infantrymen, swept away by the gigantic movement of concentration of troops prelude to the battle of the frontiers, were confronted with «long marches» that were absolutely exhausting, as much by the scale of the stages as by the environment in which they took place [Le Gall, 2014b, p. 153-158]. The French army of 1914 was almost exclusively horse-drawn.The $10^{\text {th }}$ Corps provided cars to limited officers and services: General Defforges, the treasury and post office services

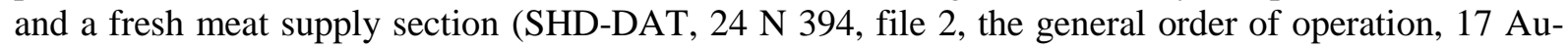
gust 1914) (for a more general approach see [Milhaud, 2017]). As a result, not only tens of thousands of feet of soldiers but almost as many horse hooves hammered these Ardennes forests on which brutal stormy rains fell in the summer of 1914. The «excessive» or even «intolerable» heat, described by several infantrymen of the $47^{\text {th }}$ IR, was followed by violent downpours which, one can easily imagine, soaked the ground[Prigent, Richard, 2010, p.8; Omnes, n.d., p. 5].

Realizing the effect of these bad weather conditions on the ground trodden by the infantrymen, we should remember that an active infantry unit such as the $47^{\text {th }}$ IR had theoretically in August 1914 starting strength of 3,300 men and 300 horses. Otherwise, a field artillery regiment represents a herd of 2,900 horses [Milhaud, 2017, p. 25]. It is precisely these orders of quantities mobilized by the Great War also make the environmental approach to the conflict necessary. The $47^{\text {th }}$ IR was only an elementary particle of a much larger whole. The $5^{\text {th }}$ Army under General Lanrezac with some 300000 men, 110000 horses and 21000 cars crossed the same Ardennes forests in the summer of 1914 ([Lanrezac, 1920, p. IX] (Miquel wrote about 290000 men and more than 100000 horses [Miquel, 2001, p. 5]).

From then on, everything leads us to believe that it is in a real dilemma that these men must advance, day and night, and at a brisk pace. Consequently, there is no doubt that not only their pants were red, on the eve of receiving the baptism of fire on 22 August 1914, but that the infantrymen were red-faced already before fighting their first battle. They were exhausted and tired because of their shoes (godillot) which waterproofness was improved only next year [Lesjean, 2019, p. 38-39]. The unpreparedness of the French army was revealed, as it enters the war based on a rather unrealized in- 
struction. The contrast is striking between these long marches of the summer of 1914 and the manoeuvres in which the $47^{\text {th }}$ IR took part just a year earlier: because of «heavy rains [...] transforming the furrows in the fields into streams and making the terrain so heavy that in many places it is impassable», the troop was granted the benefit of a two-day respite («Repos sur toute la ligne», L'OuestÉclair, 1913, September 16, № 5378, p. 1).

\section{7 th IR and pollution}

Nevertheless, there are other dangers against which it is illusory to demand the slightest respite. The idea of pollution was undoubtedly not very prevalent in 1914-1918, and the archives do not mention it explicitly. However, for those who can read between the lines, it is quite apparent that the environment in which the poilus evolved was vitiated, which had an impact on their behaviour in fire.

Despite the silence of sources, there is no doubt about the strong environmental footprint of the $47^{\text {th }}$ IR during the First World War. Itwas reflected in the proposals made on 25 March 1915 by the doctor commanding the $20^{\text {th }}$ infantry division's medical service, when the latter was positioned north of Arras. Addressed to the general commanding the division to «minimize the causes of the diseases that could result from the troops' stay in the trenches», they originated from several observations made in the field that described the environment in which the infantrymen of the $47^{\text {th }}$ IR were operating. It was recommended that «dung, the garbage of all kinds [be] buried» and that the trenches be equipped with latrines («feuillées»), which means that the poilus would relieve themselves just about anywhere they could (SHD-DAT, 26 N 301/8, JMO Service de santé 20e DI, 25 March 1915). However, sometimes the cure is worse than the disease:

«Puddles, pools of standing water, tubs or other containers filled with stagnant water are where the larvae of gnats, flies and mosquitoes, all insects that play a major role in the spread of disease, develop. It is, therefore, essential to eradicate them. It can be done by clearing streams and gutters of the demolition materials that block them and form a dam, by digging drainage channels, by filling the holes with earth, or by carefully emptying the tubs. When it is not possible to remove stagnant water by any of these means, mosquito larvae can be prevented from developing by pouring oil into the water: a simple and inexpensive way to oil the stagnant water is to soak a cloth in oil and walk it with a stick over the surface of the water. This operation must be repeated every time the layer of oil has disappeared» (SHD-DAT, 26 N 301/8, JMO Service de santé 20e DI, 25 March 1915).

It is easy to see from these few lines why the issue of water is so crucial within the $20^{\text {th }}$ division, a reality that is certainly not unique to this unit. In addition to the Germans, poilus had to fight against microbes and statistics should not be misleading in this respect. If typhoid fever seems to strike sparingly in the ranks of the $47^{\text {th }} \mathrm{IR}$, this is less due to an improvement in hygiene conditions than to the systematic vaccination campaign implemented from the winter of 1915. On the contrary, the entire incubation basin that is the battlefield seems to be a permanent feature of the war of positions [Le Gall, 2014, p. 146-149].

\section{Remnants of fights}

However, a distinction must probably be made here according to the weapon (artillerymen's serving was purer than service of infantrymen). In this respect, literature is a precious source, and countless novels are evoking the coexistence between the poilus and the rotting corpses of soldiers of all nationalities - and horses. In his Memoirs, the corporal of the $47^{\text {th }}$ IR Auguste Labbé wrote:

"What was most dreadful in our front-line trenches to see were the French corpses left on the ground from the unfortunate retreat of the first days of October [1914]: on a front 100 meters in front of us there were at least 400 corpses and they were there until I was wounded. They were flattened on the ground and in the morning they did not smell the roses, birds of prey, crows or hawks came to devour them, we shot at them, the aim was not great, so we often missed them, the bodies of these unfortunate soldiers were so flattered that we could no longer see the condoms. I was astonished that there were no epidemics on the front line when I saw that the dead were buried so shallowly, there are some who have no more than ten centimetres of the earth on them, and it is not uncommon when passing by a grave to see an arm or a leg coming out of the ground. [...]

For horses it was the same thing, they were buried so shallow that their bodies protruded above the ground and when you stepped on them you would sink into the rot and take a good perfume» (Européana 14/18: FRAD022 - Auguste Labbé). 
Although it is glacial, this painting has nothing specific to the Great War, as the historian B. Cabanes rightly points out:

«A battle is never just a paroxysmal confrontation between combatants. It leaves its mark on the natural environment, with open-air mass graves threatening to pollute rivers and cause epidemics. Hygiene concerns then recurrently return when it comes to limiting the unbearable coexistence of the living and the dead, avoiding contagions and protecting oneself from the corpses that end up cluttering up the battlefield» [Cabanes, 2018, p. 424].

However, the bodies of the victims of the fighting were one thing, the remains of the warrior act were another, even if archives are not very prolific in this regard. Nevertheless, trench art, as a prevalent practice, leaves little doubt about the thousands of shell casings littering the environment of the poilus. Still, on the subject of the Arras sector, Corporal Labbé of the $47^{\text {th }}$ IR evoked in his Memoirs«fields where there were unexploded Kraut ["Boche"] shells» (Européana 14/18: FRAD022 - Auguste Labbé.). In addition to the dangerousness of these munitions ready to explode, using of these cartridges raise the question of damage to the ground and in particular the dispersion of powders and explosives. Grenades, bullets and shells are all ecological time bombs in this respect, even if it is difficult today to grasp their exact extent.

The same applies to combat gases [Lepick, 1998]. Jean Duthu, a baker from Bagnères-deBigorre, transferred to the $47^{\text {th }}$ IR from the $130^{\text {th }} \mathrm{IR}$, was a good example since we know that his eyesand hands wereinjured by toxic gas in January 1918 that led to his death a few days later (Arch. dép. Htes-Pyrénées, 1 R 172.902). However, unfortunately, archives say nothing about the sequence of events and in particular about these toxic slicks that can float for several days on the battlefield. Here again, it is an undeniable attack on the environment of the combatants, resulting from the warlike activity, but whose real dangerousness is difficult to apprehend in the end. The work of historian O. Lepick shows that the effect of combat gases is above all psychological, as the particular example of the $47^{\text {th }}$ IR attests. Only 23 cases of «gas poisoning» were mentioned among 2688 infantrymen in this unit who passed away during the Great War [Le Gall, 2014b, p. 461].

\section{The health assessment}

In general, it is complicated to assess the mortality resulting from these environmental impacts. For example, the sources do not mention any case of lead poisoning contracted in the trenches. Nothing allows us to understand the impact of lead, which is nevertheless omnipresent, on the poilus of the $47^{\text {th }}$ IR: think of the billions of shrapnel balls in 1914-1918 [Rainhorn, 2019].

Similarly, it is difficult to attribute some viral and bacterial pathologies to the vitiated environment that is the battlefield of the Great War. The example of tuberculosis shows this. The unit's death list shows eight deaths caused by this disease but, once again, archives prove to be misleading. Indeed, this figure does not take into account the many cases of «bronchitis», «chronic bronchitis of the left vertex» or «pneumonia» found throughout the thesaurus, all of which can mask cases of tuberculosis. These are, therefore,minimal data, and do not take into account the numerous reforms resulting from this disease. Finally, archives do not allow us to conclude whether an individual contracted the pathology in the trenches, in a rear depot or even at home, before arriving in the army (for further developments [Darmon, 2002, p. 35-50; Viet, 2016, p. 52-67]).

The fact remains that the Great War is part of an astonishing paradox that the example of the $47^{\text {th }}$ IR allows us to highlight. Because of medical progress, the disease killed less than shells and bullets: of the 2688 deaths in the IR, only 144 deaths were attributed to «illness in service». Typhus, malaria, smallpox, diphtheria, dysentery, tuberculosis and meningitis, not forgetting, of course, the socalled Spanish flu, are only a small portion of the causes of death, whereas the (over)living conditions in the trenches make them perfect incubation basins. While these rates of mortality due to disease underline the efficacy of vaccines in pathology such as typhoid, they should not obscure the appalling bacteriological environment in which infantrymen operate. Finally, it is essential to bear in mind that since the archives do not bear witness to the post-conflict medical follow-up of the poilus, there is no way of assessing the health impact of pollution caused by the tons of ammunition dumped on the battlefield. The same applies to combat gases, whether asphyxiating or blistering. 


\section{War as the domination of nature}

The environmental approach of the $47^{\text {th }}$ IR campaign provides a fresh insight into the tactical configuration of the regiment between 1914 and 1918. Indeed, the attention paid to viruses and bacteria, but also soils and climatic conditions, invites us to ask ourselves whether, in the end, combat does not require, above all else, to dominate nature in order to hope to prevail over the enemy.

One of the most insidious enemies faced by the infantrymen of the $47^{\text {th }}$ IR is undoubtedly rain. Initially from Plouha, in the Côtes-du-Nord region, Yves Le Guen declared he was a farmer when he appeared before the Board of Revision. Used to live in the great outdoors, he confessed to his mother in February 1915 (Arch. dép. 22: 1 R 1302.1220):

«You have to see to realize that after spending 2 or 3 days of rank in the kingdom of moles you are more or less dirty. When it rains, each of us has dragged at least $40 \mathrm{~kg}$ of mud» (Jean-Claude Le Guen Private Archives: Letter from Yves Le Guen to his mother, 14 February 1915).

Emile Le Guen, brother of Yves, also mobilized in the $47^{\text {th }}$ IR, explained a year later, in a letter dated 15 February 1916:

«The trenches are pitiful: no matter how much water is driven into them, they fill up immediately. [...] I often go to the front line to carry materials against asphyxiating gases, and I assure you that when I come back, I am like a pile of mud» (Jean-Claude Le Guen Private Archives: Letter from Emile Le Guen to Queen, 15 February 1916).

One can imagine that this permanent humidity is even more difficult to bear for Auguste Labbé, a recipes boy from Galeries Lafayette whom the war sends to the $47^{\text {th }}$ IR. Living in an urban environment and accustomed to an individual «modern comfort», he is probably even less prepared than the Le Guen brothers to evolve in such an environment. In his notebooks, he describes trenches invaded by «thirty centimetres of water», which says how much this degraded environment can weigh on the morale of the combatants.

The same applies to temperatures, whether they are high or on the contrary rigorous. We saw earlier how physically demanding the long marches of the summer of 1914 were for the infantrymen of the $47^{\text {th }}$ IR. It was on 8 August 1914 that the first death of the unit was recorded: Antoine Blandin, a fitter born in Saint-Malo and killed not by a burst of machine-gun or a German shell but by «heatstroke», in other words, sunstroke (Arch. dép. I\&V: $1 \mathrm{R}$ 2050.502). News of this death spread very quickly through the ranks, causing a particular drop in the morale of the troop [Le Gall, 2014b, p.162-163]. Conversely, Yves Le Guen explained to his mother in a letter dated 20 November 1914:

«Today the traffic is tough because of this icy snow. We suffer a lot from this weather although we are well dressed...» (Jean-Claude Le Guen Private Archives: Letter from Yves Le Guen to his mother, 20 November 1914).

Auguste Labbé, referring to the winter of 1914-1915 when the $47^{\text {th }}$ IR was north of Arras, reports that he «saw more than once [his] soup frozen in [his] bowl and the portion frozen to the point of being unable to carve it» (Européana 14/18: FRAD022 - Auguste Labbé).

\section{Managing the space}

Visibility, on the other hand, is a much more ambivalent hazard since the unit occasionally knows how to deal with this data to turn it to its advantage. Indeed, in May 1915, General d'Urbal, commanding the $10^{\text {th }}$ army, argued that the weather conditions were unfavourable, particularly for aerial reconnaissance, when he decided to postpone for 24 hours the attack he was to make in Artois, in which the regiment was to participate [Le Gall, 2014b, p. 130-133]. In the same way, in 1914, the $47^{\text {th }}$ RI proved to be heavily handicapped by fog during the battles of Charleroi and Guise, then by night during this Race to the Sea which led it to operate south of Arras [Le Gall, 2014b, p. 130-133]. The lack of visibility was a problem in case of assault but also when it was a question of protecting itself from an enemy attack. Thus, a summons to order given to a stretcher-bearer of the $47^{\text {th }}$ IR mentions searchlights aimed at the German trenches, a device found in other places on the front («Remise de decoration», Le Salut, 1915, December 10-11, № 96. P. 2). Being in the Verdun sector, JeanBaptiste Blazy Lauzette noted on 11 December 1914: «The Germans throw on our lines light of the electric projectors illuminated the nights to see if we are advancing or working» [Collognat-Bares, 2014, p. 72]. On the other hand, the infantrymen of the 47th IR also knew how to take advantage of the fog and darkness to operate discreetly in no-man's-land or to recognize enemy lines [Bazin, 1921, p. 216-217]. 
Nevertheless, it must be said that as soon as the unit is forced to move and discover a new theatre of operation, it encounters incredible difficulties, as if it were blinded by a lack of knowledge of the terrain. The battles that the $47^{\text {th }}$ IR fought south of Arras in the early days of October 1914 were symptomatic. Whereas two weeks earlier the unit had shown a remarkable adaptation to the imperatives of modern warfare, evolving on the battlefield in small groups and achieving perfect liaison with artillery, it appeared in the vicinity of Mercatel wholly disoriented, as if lost among the elements of the $10^{\text {th }}$ Corps and unable to find its way around the theatre of operations [Le Gall, 2014b] [Le Gall, 2012, p. 261-268]. This difficulty in adapting to new terrain seems to be a constant. During the summer of 1918, operating more or less where it had been engaged four years earlier, in September 1914, between the Marne and the Vesle, the regiment faced very similar difficulties - inherent to the war of movement - and proved almost as incapable of overcoming them properly. Prisoners of the emptiness of the battlefield and lacking a global vision of operations, the infantrymen were isolated from the chain of command, deprived of intelligence and, above all, of supplies [Le Gall, 2014, p. 243-247].

\section{Conclusion}

From then on, the environmental approach of the $47^{\text {th }}$ IR campaign invites us to look at the unit through the prism of learning curves to see whether it improved its fighting capabilities between August 1914 and November 1918. As far as the ability to find one's way in new terrain is concerned, it seems that the answer must be a very measured one. Indeed, the regiment does not manage to get rid of the cultural patterns inherited from the Belle Epoque to adapt to the reality of modern combat. The terrain and the same modalities of engagement render obsolete the bonds of authority that may prevail in the depot or rest quarters and which, fundamentally, are inherited from peacetime. It is well known that the closer one gets to no man's land, the more the bonds of discipline become distended. The corollary of combat is to interrupt hierarchies by isolating men on the battlefield in small groups. The smoke released by the ammunition and the absolute necessity to lie down or risk being hit by a projectile, not to mention the adrenaline and the upheavals of the terrain, are all factors that alter the field of vision and make this motivation by the example so prized by the officers of the Belle Epoque completely ineffective [Cochet, Porte, 2017, p. 210]. Indeed, the latter is conveyed by capillarity, and in the absence of visual contact, the good action is lost, useless, in the limbo of the battlefield. The same is true of encouragement and other words full of drive which, even if they are shouted, are necessarily covered by the noise of the machine guns and even more so of the artillery. The death on 9 September 1914 of Lieutenant Colonel Poncet des Nouailles is entirely significant in this respect. Despite «extremely violent and admirably regulated artillery and musketry fire», the commander of the $47^{\text {th }}$ IR

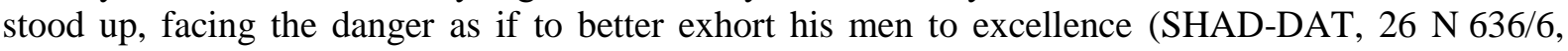
JMO 47th IR, 9 September 1914). However, the scope of this bravery is almost nil, since neither Louis Leseux nor Albert Omnès, nor Marcel Brégé mentioned it in their respective notebooks. Moreover, for a good reason, everything leads us to believe that they did not see the exemplary conduct of the commander of the unit, and therefore could not react to the visual stimulus that was nevertheless intended for them [Le Gall, 2014a, p. 21-31].

Analysis of mortality statistics in the $47^{\text {th }}$ IR shows that the unit never really manages to break free from the grip of winter. The months from November to March show a slowdown in mortality, since they accounted for only $9.8 \%$ of all deaths in 1915, a proportion that rose to $16.7 \%$ in 1916 , $5.8 \%$ in 1917 and $12.2 \%$ in 1918. Conversely, the months of April to October concentrated the losses: 330 in June 1915, 101 in September 1916 and 107 in September 1917. In other words, regardless of the constant increase in its firepower and its continuous mechanization, the regiment fought throughout the Great War mainly between spring and autumn [Le Gall, 2014b, p.256-257].

Moreover, throughout the campaign, the regiment was subjected to climatic conditions, which could radically impact its warrior capacities. On 26 June 1915, the report of the 24 hours spent at the level of the $20^{\text {th }}$ ID notes that the $47^{\text {th }}$ IR, then engaged in the formidable sector of the Labyrinth, suffered greatly from the climatic conditions: «mud and rain greatly hampered the attackers who could not succeed». Moreover, the same document, definitive: «the bad weather considerably hindered the execution of the work» (SHD-DAT, 24 N 396, file 1, 24-hour report, 26 June 1915). It was the same in the summer of 1918, even if the tactical configuration of the battlefield on which the regiment was operating, a return to the war of movement, was radically different. Second lieutenant Fred Aubert of the 7/47th RI recalls in his notebooks: 
«The captain points out a salient that I must occupy with my section reinforced with a machinegun section. But the night surprises me. I wander across the plain in the rain with my men behind me. I search in vain for the salient assigned to me. From time to time, I glimpse darker shadows. The Krauts or the French? Gun in hand, neck outstretched, I walk blindly, dragging my men who, exhausted, walk like automatons whose tired springs only generate a prolonged movement and who no longer even have the strength to complain» (Aubert, undated, p. 29).

While it is customary to describe the Great War as the confrontation of increasingly powerful troops, industrial conflict in which man, struck down by fire and steel, no longer has a place on the «field of honour», the environmental approach of the $47^{\text {th }}$ IR campaign suggests a significantly different reality. Indeed, in many ways, the regiment seems to be a prisoner of Mother Nature.

\section{Sources}

Allard, J. (2010), Journal d'un gendarme 1914-1916, Bayard, Paris, 258 p.

Archives dép. Côtes-d'Armor, 1 R 1302.1220.

Archives dép. Hautes-Pyrénées, 1 R 172.902.

Archives dép. Ille-et-Vilaine, 1 R 1931.598.

Archives dép. Ille-et-Vilaine, 1 R 2050.502.

Aubert, F. (undated), Avec ma section: 27 mai 1918 - 15 août 1918, Editions Cendrillon, SaintBrieuc, 65 p.

«Comment fut pris le Mont Cornillet», L'Ouest-Éclair, 1917, June 3, № 6420.

FRAD022 - Auguste Labbé, Européana 14/18. URL: https://www.europeana.eu/en/item/2020601/ https__1914_1918_europeana_eu_contributions_15668 (дата обращения: 20.12.2020).

Jean-Claude Le Guen Private Archives, Letter from Emile Le Guen to Queen, February 15, 1916.

Jean-Claude Le Guen Private Archives, Letter from Yves Le Guen to his mother, February 14, 1915.

Jean-Claude Le Guen Private Archives, Letter from Yves Le Guen to his mother, November 20, 1914.

Omnes A. (undated), Carnet de route, campagne 1914, Notes et impressions prises par le sergent Omnes du 47e régiment d'infanterie, Bretagne 14-18, Plessala, 27 p.

«Remise de decoration», Le Salut, 1915, December 10-11, № 96.

«Repos sur toute la ligne», L'Ouest-Éclair, 1913, September 16, № 5378.

Service historique de la Défense. Le Département de l'armée de Terre (SHD-DAT), 26 N 636/6, JMO 47th IR, 9 September 1914.

SHD-DAT, 24 N 394, file 2, ordre generale des operations, 17 August 1914.

SHD-DAT, 24 N 396, file 1, 24-hour report, 26 June 1915.

SHD-DAT, 26 N 301/8, JMO Service de santé 20e DI, March 25, 1915.

SHD-DAT, 26 N 636/8, JMO 47th RI, 4-6 September 1916.

SHD-DAT, 26 N 636/9, JMO 47th IR, 30 April 1917.

\section{References}

Historique du 47e régiment d'infanterie (1920), J. Haize, Saint-Servan, France, 40 p.

Audoin-Rouzeau, S. \& A. Becker (2000), 14-18, retrouver la Guerre, Gallimard, Paris, France, 398 p.

Bazin, Y. (1921), Livre d'or des anciens élèves du collège de Saint-Malo morts pour la France, Imprimerie R. Bazin, Saint-Malo, France, 272 p.

Cabanes, B. (dir.) et Dodman, T., Mazurel, H. \& G. Tempest (coord.) (2018), Une histoire de la guerre du XIXe siècle à nos jours, Seuil, Paris, France, $800 \mathrm{p}$.

Cochet, F. \& R. Porte (2017), Histoire de l'armée française 1914-1918. Evolutions et adaptations des hommes, des matériels et des doctrines, Tallandier, Paris, France, $519 \mathrm{p}$.

Collognat-Bares, A. (2014), Trois frères dans la Grande Guerre, Hachette, Paris, France, 258 p.

Darmon, P. (2002), «La Grande Guerre des soldats tuberculeux. Hôpitaux et stations sanitaires», Annales de démographie historique, № 1 (103), pp. 35-50.

Fressoz, J.-B., Graber, F., Locher, F. \& G. Quenet (2014), Introduction à l'histoire environnementale, La Découverte, Paris, France, 125 p.

Keegan, J. (2012), The face of the battle. A study of Agincourt, Waterloo and the Somme, Random House, London, UK, 352 p. 
Lanrezac, C. (1920), Le plan de campagne français et le premier mois de la guerre (2 August - 3 September 1914), Payot, Paris, France, 284 p.

Le Gall, E. (2012), «Investir la culture de guerre du premier conflit mondial? Le 47e régiment d'infanterie au fort de la Pompelle, 13-17 septembre 1914», Bulletins et mémoires de la Société archéologique \& historique d'Ille-et-Vilaine, pp. 261-286.

Le Gall, E. (2014a), «La Marne ou le champ d'honneur du colonel Poncet des Nouailles», in Joret, E. \& Y. Lagadec (eds.), Hommes et femmes d'Ille-et-Vilaine dans la Grande Guerre, Conseil général d'Ille-et-Vilaine, Société archéologique et historique d'Ille-et-Vilaine, Rennes, France, pp. 21-31.

Le Gall, E. (2014b), Une entrée en guerre. Le 47e régiment d'infanterie de Saint-Malo au combat (août 1914 - juillet 1915), CODEX, Talmont-Saint-Hilaire, France, 277 p.

Le Gall, E. (2017), «15 juin 1917: le 47e RI arrive à Verdun. La découverte de la vraie guerre?», Bulletins de la société d'émulation des Côtes d'Armor, pp. 213-239.

Le Gall, E. (2019), Le 47e régiment d'infanterie pendant la Première Guerre mondiale, thèse présentée et soutenue à Rennes, le 13 décembre 2019, Université Rennes 2, Rennes, 585 p. URL: https://tel.archives-ouvertes.fr/tel-02930862 (accessed 21.12.2020).

Lepick, O. (1998), La Grande Guerre chimique 1914-1918, Presses universitaires de France, Paris, France, XXIV, 315 p.

Lesjean, F. (2019), «Marcher et combattre. Archéologie de la protection du pied du combatant», in Harismendy, P. \& E. Le Gall (eds.), Un Adieu aux armes. Destins d'objets en situation de post-guerre, Presses universitaires de Rennes, Rennes, France, pp. 37-46.

Locher, F. \& G. Quenet (2009), «L'Histoire environnementale : origines, enjeux et perspectives d'un nouveau chantier», Revue d'histoire moderne \& contemporaine, № 4 (56-4), pp. 7-38.

Milhaud, C. (2017), 1914-1918: L'autre hécatombe: Enquête sur la perte de 1140000 chevaux et mulets, Belin, Paris, France, 300 p.

Miquel, P. (2001), Le gâchis des généraux, les erreurs de commandement pendant la guerre de 14/18, Plon, Paris, France, 242 p.

Nash, R. (1972), «American environmental history: a new teaching frontier», Pacifical Historical Review, vol. 41, № 3, pp. 362-372.

Pellistrandi, J. (2020), «1870, 1914, 1940... Leçons ou sanctions?», Inflexions, № 3 (45), pp. 71-77.

Prigent, J. \& R. Richard (2010), «Un brancardier du 47e RI de Saint-Malo en campagne: Marcel Brégé», Bulletin de liaison et d'information de l'association Bretagne 14-18, June, № 53, pp. 7-12.

Prost, A. (2002), «La guerre de 14 n'est pas perdu», Le Mouvement social, № 199, pp. 95-102.

Prost, A. \& J. Winter (2004), Penser la Grande Guerre. Un essai d'historiographie, Seuil, Paris, France, $304 \mathrm{p}$.

Rainhorn, J. (2019), Blanc de plomb. Histoire d'un poison legal, Presses de Sciences Po, Paris, France, $376 \mathrm{p}$.

Viet, V. (2016), «La Grande Guerre et la lutte antituberculose en France», Revue d'histoire de la protection sociale, 2016, № 1 (9), pp. 52-67.

Дата поступления рукописи в редакцию 23.12.2020

\section{7-Й ПЕХОТНЫЙ ПОЛК ФРАНЦУЗСКОЙ АРМИИ В ГОДЫ ПЕРВОЙ МИРОВОЙ ВОЙНЫ: К ВОПРОСУ О ВЛИЯНИИ ОКРУЖАЮЩЕЙ СРЕДЫ НА БОЕВЫЕ ДЕЙСТВИЯ}

\section{Э. Ле Галл}

Центр бретонских и кельтских исследований, Университет Ренн II, Ренн, Площадь ректора Анри Ле Моала, CS 24307-35043

legallerwan@ymail.com

ORCID: 0000-0001-7807-4569

ResearcherID: E-1884-2014

Первая мировая война может быть рассмотрена не только с точки зрения традиционной военной истории, но также с позиции взаимоотношения участников боевых действий и окружающей среды. На основе широкого круга архивных материалов, печатных СМИ, а также эго-документов (дневников, воспоминаний, 
писем) раскрывается вопрос о боевых особенностях 47-го пехотного полка французской армии в связи с влиянием на военнослужащих условий окружающей среды. Показана зависимость интенсивности и результативности боевых действий полка на Западном фронте Первой мировой войны от состояния местности, погоды, изменений климата. Уже на первой стадии мирового конфликта солдаты оказались чрезвычайно уязвимы к малейшим изменениям в температурном режиме (сильная жара, холод) из-за проблем с обмундированием. Вместе с тем негативное влияние на здоровье оказывали физические перегрузки из-за долгих переходов по незнакомой пересеченной местности, а потом длительное пребывание в окопах. Подчеркивается также активное влияние боевого подразделения на окружающую среду: местность, где проходили бои, загрязнялась нечистотами, остатками боеприпасов и оружия. Кроме того, рассматривается проблема негативного воздействия загрязненной окружающей среды на самих солдат (прежде всего распространение заразных болезней, отравление боевыми химическими веществами и металлами). Сильное изменение окружающей среды в ходе сражений также затрудняло ведение боевых действий. Таким образом, в годы Первой мировой войны как военнослужащие 47-го пехотного полка французской армии, так и все остальные «пуалю» становились заложниками природы, сильно изменившейся из-за воздействия миллионов комбатантов.

Ключевые слова: французская армия, Первая мировая война, пехота, 47-й полк, военные действия, окружающая среда. 